\title{
How Efficient the Islamic Banking Model is in Pakistan?
}

\section{Tahseen Mohsin Khan*, Hamza Rizwan ${ }^{* *}$, Saima Akhtar ${ }^{* * *}$, and Syed Waqar Azeem Naqvi****}

\begin{abstract}
The purpose of this study is to analyze and evaluate the conventional and Islamic banking in Pakistan. For this study, sample of 19 conventional banks and 5 Islamic banks were selected. Camels approach is being used to evaluate the performance of both the conventional and Islamic banks. Ten ratios were used to measure profitability, liquidity, credit risk. Findings suggest that Islamic banks are less efficient than conventional banks in sectors like Asset Management, Management Capabilities and Liquidity. Also, the conventional banks have better Earning capabilities in terms of Return on Asset and Overhead Ratio. The analysis also shows that Islamic banks has better capital adequacy for the five years than conventional banks. The study also has implications for bankers as well as policy makers.
\end{abstract}

Keywords: Islamic Banking, Efficiency, CAMEL, Capital Adequacy

JEL Codes: G21, N20, Z12

\footnotetext{
${ }^{*}$ Assistant Professor at University of Management and Technology (UMT), Lahore

${ }^{* *}$ Credit Analyst at JCR-VIS

${ }^{* * *}$ Lecturer at CIIT Lahore

${ }^{* * * *}$ Assistant Professor at University of Sargodha, Lahore Campus
} 